\title{
ОЦЕНКА СОЦИАЛЬНОГО САМОЧУВСТВИЯ СОВРЕМЕННОЙ МОЛОДЕЖИ ${ }^{1}$
}

\author{
Е.В. Желнина \\ (https://orcid.org/0000-0002-0332-1382),
}

\section{А.Е. Савельева}

Тольяттинский государственный университет, Тольятти, Россия, e-mail:ezhelnina@yandex.ru,annasaweljewa9@yandex.ru

\section{DOI: $10.14258 / \operatorname{ssi}(2019) 4-11$}

Представлены результаты эмпирического исследования социального самочувствия современной молодежи крупного промышленного города. Целью исследования стал анализ особенностей социального самочувствия молодых людей с использованием типовой методики, разработанной Центром изучения социокультурных изменений ИФ РАН под руководством член-корреспондента РАН Н.И. Лапина, «Социокультурный портрет региона», которая позволила рассчитать индекс социального самочувствия на основе трех его базовых значений: коэффициент защищенности, коэффициент удовлетворенности и коэффициент оптимизма. Кроме того, в работе использованы данные, полученные в результате проведения биографического интервью. При сборе эмпирических данных для расчета индекса социального самочувствия был выбран метод опроса (анкетирование). В процессе исследования было выяснено, что в целом молодые люди оценивают город положительно, отмечая, что он вызывает у них чувства симпатии, любви или равнодушия. Однако такие аспекты, как трудоустройство по специальности, обеспечение медицинских услуг, качество и уровень жизни, внешний облик городского пространства, по мнению респондентов, находятся на низком уровне. Индекс социального самочувствия молодых людей составил 0,7. Данное значение определяет высокий уровень социального настроения, защищенности и удовлетворенности жизни молодежи. Посредством использования качественного метода социологического исследования - биографического интервью было изучено и проанализировано отношение респондентов к городу, выявлены его достоинства и недостатки, определены планы молодых людей на будущее и жизненные перспективы.

Ключевые слова: сочиальное самочувствие, молодежь, эмпирическое исследование, анкетирование, биографическое интервью, методика расчета.

\footnotetext{
${ }^{1}$ Статья публикуется при поддержке гранта РГНФ «Концептуальная модель региональной идентичности населения Самарского региона» (18-411-630001).
} 


\title{
ASSESSMENT OF SOCIAL WELL-BEING OF MODERN YOUTH
}

\author{
E.V. Zhelnina \\ (https://orcid.org/0000-0002-0332-1382) \\ A.E. Savelyeva \\ Togliatti state University, Togliatti, Russia, \\ email: ezhelnina@yandex.ru, annasaweljewa9@yandex.ru
}

The article presents the results of an empirical study of the social well-being of modern youth of a large industrial city. The aim of the study was the analysis of peculiarities of social well-being of young people using the standardized methodology developed by the Center for the study of social and cultural change N. I. Lapina «Socio-cultural portrait of the region», which allowed to calculate the index of social well-being based on three baseline values: a security ratio of ratio of satisfaction and the coefficient of optimism. In addition, the data obtained as a result of the biographical interview were used in the work. To collect empirical data for the calculation of the index of social well-being, the survey method (questionnaire) was chosen. In the course of the study, it was found that in General, young people evaluate the city positively, noting that it causes them feelings of sympathy, love or indifference. However, such aspects as employment in the specialty, provision of medical services, quality and standard of living, the appearance of urban space, according to respondents, are at a low level. The index of social well-being of young people was 0.7 . This value determines the high level of social mood, security and satisfaction of young people's lives. Through the use of qualitative method of sociological research-biographical interview, the attitude of respondents to the city was studied and analyzed, its advantages and disadvantages were revealed, plans of young people for the future and life prospects were determined.

Keywords: social well-being, youth, empirical research, questionnaire, biographical interview, calculation method.

В условиях трансформации российского общества все более актуальным становится вопрос, связанный с социальным самочувствием молодых людей, от которых зависит будущее нашего общества. Частые изменения в таких сферах жизни общества, как экономическая, социальная, политическая и духовная, способны повлиять на внутренние чувства людей: защищенности, оптимизма и «веры в будущее», а также на их стабильность. Все это может привести к утрате внутренних ориентиров отдельно взятой личности. Отсюда возрастает напряженность и социальная неопределенность в обществе. Особенно остро эти проблемы предстают перед молодым поколением в силу того, что именно оно наиболее восприимчиво к переменам, происходящим в социуме.

Актуальность данной проблемы в нашей стране также можно обосновать тем, что регулярно ВЦИОМ проводит мониторинги социального самочувствия россиян, 
демонстрируя, как меняются индексы оценок населения экономического, политического положения в стране, а также материального благополучия, удовлетворенности жизнью, социального оптимизма (Социальное самочувствие...).

Что же касается промышленного моногорода Тольятти, то в 2015 г. Росгосстрах провел исследование о качестве жизни в крупных городах. Участниками стали около 22 тысяч жителей из 38 крупных населенных пунктов. Среди них оказались Самара и Тольятти. Респондентам задавались вопросы, касающиеся работы местной администрации, общественного транспорта, состояния ЖКХ, услуг медицины и образования, а также удобства города в целом для постоянного проживания. Среди тольяттинцев комфортным свой город считают лишь 59\% опрошенных. По данным опроса Тольятти занимает лишь 36-е место из 38 по удобству и комфорту. Всего $28 \%$ жителей Автограда удовлетворены местной медициной и 58\% - образованием. Лишь половина опрошенных считают, что в городе достаточно культурных учреждений. Эти показатели являются самыми низкими по стране. Только $25 \%$ тольяттинцев уверены, что местная администрация делает многое для благополучия и развития города (Качество жизни...).

Поэтому стоит отметить наличие и особую актуальность данной проблемы и заметить, что ее корни уходят глубоко в историю нашего общества и государства. Данную проблему необходимо решать не только на государственном, но и на местном уровне.

В современном обществе важной социокультурной характеристикой населения является социальное самочувствие. В нашем исследовании изучалось социальное самочувствие молодежи - социально-демографической группы, обладающей набором социальных качеств, выражаемых через ценностные установки, жизненную ориентацию, статус и субкультуру, восприимчивую к переменам, происходящим в социуме.

Целью нашего исследования являлся анализ социального самочувствия молодежи в крупном промышленном городе Тольятти. Благодаря полученным данным анкетного опроса мы выяснили, что в целом молодые тольяттинцы оценивают город положительно, отмечая, что он вызывает у них чувства симпатии (34\%), любви (28\%) или равнодушия (22\%). Однако такие аспекты, как трудоустройство по специальности, обеспечение медицинских услуг, качество и уровень жизни, внешний облик городского пространства, по мнению респондентов, находятся на низком уровне. Высоко оценивают молодые люди дорожную сеть г. Тольятти. Актуальными социальными проблемами промышленного города тольяттинская молодежь называет безработицу, низкий уровень жизни, экологическую проблему, а также инфляцию и рост цен. Относительно планов миграции людей в возрасте 18-35 лет можно сказать, что планирующих (38\%) и не планирующих (40\%) переезд оказалось почти равное число респондентов.

В нашем исследовании мы использовали типовую методику, разработанную Центром изучения социокультурных изменений ИФ РАН под руководством член-корреспондента РАН Н.И. Лапина, «Социокультурный портрет региона», которая позволила рассчитать индекс социального самочувствия на основе трех его 
базовых значений: коэффициент защищенности, коэффициент удовлетворенности и коэффициент оптимизма.

Наиболее незащищенными чувствуют себя молодые тольяттинцы от таких угроз, как экологическая ситуация $(0,52)$, а также произвол правоохранительных органов $(0,53)$. Эти значения являются граничащими с критичным значением индекса социального самочувствия (ниже 0,51). Высокие показатели были получены о защищенности молодежи в возрасте 18-35 лет от таких опасностей, как притеснения из-за возраста и пола $(0,8)$, притеснения за религиозные убеждения $(0,8)$, а также ущемления из-за национальности $(0,83)$. Общий коэффициент защищенности молодых тольяттинцев оказался равен 0,68 .

Коэффициент удовлетворенности был рассчитан на основе вопроса анкеты о том, насколько молодые люди удовлетворены своей жизнью в целом. Данный показатель равен 0,71. Также был рассчитан коэффициент оптимизма $(0,7)$. Индекс социального самочувствия рассчитывается как среднее суммы трех названных коэффициентов. Таким образом, индекс социального самочувствия молодых людей г. Тольятти составил 0,7. Данное значение определяет высокий уровень социального настроения, защищенности и удовлетворенности жизни молодежи.

Благодаря качественному методу исследования - биографическому интервью мы глубинно изучили и проанализировали ответы респондентов об их отношении к г. Тольятти, о его достоинствах и недостатках, планах на будущее и жизненных перспективах, а также качество жизни молодежи с позиций жилья, взаимоотношений с окружающими, занятия любимым делом и др. Главными сильными сторонами Тольятти молодые люди назвали: природную красоту города, наличие автомобильной промышленности, удобство дорожной сети. Были отмечены и слабые стороны, среди них оказались: безработица, отсутствие запоминающейся архитектуры, малое количество мест для отдыха, плохая экологическая ситуация. Для многих респондентов г. Тольятти не является комфортным для жизни. Комфортная среда, по мнению молодых людей, - это городское пространство с развитой инфраструктурой, благоприятной экологической обстановкой и наличием парковых зон и мест отдыха и спорта. Исходя из ответов респондентов о том, что для них счастье и считают ли они себя счастливыми, можно сказать, что в понятие «счастье» молодежь вкладывает наличие четырех базовых ценностных компонентов: семья, любимая работа, здоровье и друзья.

Подводя итоги, можно сказать, что мы достигли поставленных в исследовании целей и задач. Несмотря на то, что в современном обществе понятие «социальное самочувствие» не имеет четкого определения, его изучение важно для измерения социальных настроений, жизненных ориентаций населения в каждом регионе и в целом по стране. Благодаря проведенным исследованиям мы выяснили, что социальное самочувствие молодежи г. Тольятти находится на высоком уровне, несмотря на все названные респондентами социальные проблемы города. 


\section{БИБЛИОГРАФИЧЕСКИЙ СПИСОК}

Социальное самочувствие россиян: пресс-выпуск № 3437. Опросы ВЦИOM. URL: https://wciom.ru/index.php?id=236\&uid=116346 (дата обращения: 16.08.2019).

Качество жизни в Самаре и Тольятти: Исследование. Большая деревня. URL: https:// bigvill.ru/city/8408-issledovanie-kachestvo-zhizni-v-samare-i-tolyatti/ (дата обращения: 17.07.2019).

\section{REFERENCES}

Sotsial'noye samochuvstviye rossiyan: press-vypusk № 3437. Oprosy VTSIOM [Social Well-being of Russians: Press Release No. 3437. VCIOM Surveys]. Available at: https:// wciom.ru/index.php?id=236\&uid=116346 (date of the application: 16.08.2019).

Kachestvo zhizni v Samare i Tol'yatti: Issledovaniye. Bol'shaya derevnya [Quality of Life in Samara and Tolyatti: A Study. Big village]. Available at: https://bigvill.ru/city/8408-issledovanie-kachestvo-zhizni-v-samare-i-tolyatti/ (date of the application: 17.07.2019). 